A Journal of Culture, English Language, Teaching \& Literature ISSN 1414-3320 (Print), ISSN 2502-4914 (Online)

Vol. 19 No.2; December 2019

Copyright (@) Soegijapranata Catholic University, Indonesia

Revealing Translation Techniques Applied in the Translation of Batik Motif Names in See Instagram

\author{
${ }^{1}$ Dyah Raina Purwaningsih, ${ }^{2}$ Ika Maratus Sholikhah, \\ ${ }^{3}$ Erna Wardani \\ ${ }^{1,2}$ English Department, Faculty of Humanities, Universitas \\ Jenderal Soedirman, Purwokerto, Indonesia \\ ${ }^{3}$ Language Education Department, Faculty of Humanities, \\ Universitas Jenderal Soedirman, Purwokerto, Indonesia \\ email: '1yah.purwaningsih@unsoed.ac.id, \\ 2ika.sholikhah@unsoed.ac.id, ${ }^{3}$ erna.wardani@unsoed.ac.id
}

Received: $25-06-2019$

Accepted: 29-08-2019

Published: 5-12-2019 


\title{
Revealing Translation Techniques Applied in the Translation of Batik Motif Names in See Translation
}

\author{
${ }^{1}$ Dyah Raina Purwaningsih, ${ }^{2}$ Ika Maratus Sholikhah, \\ and ${ }^{3}$ Erna Wardani \\ 1dyah.purwaningsih@unsoed.ac.id, \\ 2ika.sholikhah@unsoed.ac.id, ${ }^{3}$ erna.wardani@unsoed.ac.id \\ 1,2 English Department, Faculty of Humanities, Universitas \\ Jenderal Soedirman, Purwokerto, Indonesia \\ ${ }^{3}$ Language Education Department, Faculty of Humanities, \\ Universitas Jenderal Soedirman, Purwokerto, Indonesia
}

\begin{abstract}
This article discusses one of the forms of machine translation, the Instagram translation feature called "see translation". The research is focused on the translation techniques applied by the machine in translating Banyumas batik motifs from Indonesian to English found in @batikantodjamil and @batk_rd. This topic is worth discussing since machine translation is now getting more developed and is projected to replace human translator. However, in some cases, for example in dealing with culturally-bound terms, machine translation cannot perform contextual knowledge as well as the human translator. This mini research was conducted by applying qualitative research with purposive sampling technique in which the researchers obtain the data by selecting two batik center Instagram accounts containing batik motif names in the captions. The result shows that there are three translation techniques applied by the Instagram translation features, namely literal, borrowing, and particularization. The most dominant technique to use is borrowing technique, and it shows a tendency that such cultural terms in the source language do not have one-to-one correspondence in the target language. In other words, the touch of human translator is very important in the post-editing process of translation by machine to make the translation more acceptable. However, if it is impossible to involve human translator, the Instagram administrator should enrich the machine with more contextual linguistic database to provide the users with better translation results.
\end{abstract}


288 Celt: A Journal of Culture, English Language Teaching \& Literature, Volume 19, Number 2, December 2019, pp. 287 - 301

Key words: batik, culturally-bound terms, machine translation, translation technique, acceptability

\begin{abstract}
Abstrak: Artikel ini membahas salah satu bentuk Machine Translation, dalam bentuk fitur terjemahan Instagram "See Translation". Penelitian terfokus pada teknik terjemahan yang digunakan oleh mesin dalam menerjemahkan motif batik Banyumas dari bahasa Indonesia ke bahasa Inggris yang ditemukan dalam akun Instagram@batikantodjamildan @batk_rd. Topikini layak dibahas karena terjemahan mesin sekarang semakin berkembang dan diproyeksikan untuk menggantikan penerjemah manusia. Namun, dalam beberapa kasus, misalnya yang dengan istilah budaya, terjemahan mesin tidak dapat menggunakan pengetahuan kontekstual seperti yang dapat dilakukan oleh penerjemah manusia. Penelitian kecil ini dilakukan dengan menerapkan penelitian kualitatif dengan teknik purposive sampling di mana para peneliti mengumpulkan data dari dua akun Instagram pusat batik yang berisi nama-nama motif batik. Hasil penelitian menunjukkan bahwa ada tiga teknik terjemahan yang diterapkan oleh fitur terjemahan Instagram, yaitu literal, borrowing, dan partikularization. Teknik yang paling dominan untuk digunakan adalah teknik borrowing, yang menunjukkan kecenderungan bahwa istilah budaya seperti itu dalam bahasa sumber tidak memiliki padanan satusatu dalam bahasa sasaran. Dengan kata lain, sentuhan penerjemah manusia sangat penting dalam proses post-editing oleh mesin agar terjemahan yang dihasilkan lebih berterima. Namun, jika tidak mungkin melibatkan penerjemah manusia, administrator Instagram harus memperkaya mesin dengan basis data linguistik yang lebih kontekstual untuk memberikan hasil terjemahan yang lebih baik kepada pengguna.
\end{abstract}

Kata kunci: batik, istilah terkait budaya, machine translation, teknik penerjemahan, keberterimaan

\title{
INTRODUCTION
}

Seeing the phenomenon of the emergence of MT in wide range and function of human communication, the researchers are interested in bringing this topic to discussion. Moreover, research on Instagram translation feature is still rarely found due to the novelty of the aspect. This research is expected to give a contribution to the development of translation research area.

Besides analyzing translation technique, the researchers would also like to see the effect of the technique to the acceptability of the translation in the source language (SL), which is English in this case. The reason why the acceptability of the translation is important to discuss is because the data are in 
form of culturally-bound terms, especially Javanese cultural terms, which theoretically need to be treated specially when rendered to another language.

In assessing the acceptability of the translation, the researchers applied semantic analysis on the lexical items constructing the cultural terms to see whether the SL word is equally translated to the TL word or not. Nearly similar research was conducted by (Pudjiati, 2018) who evaluated the semantic errors in the Instagram machine translation of HTI account captions. The research shows that there are errors in grammatical, contextual, and referential meanings. There is also previous research dealing with the loss and gain of the translation of culture-specific items with Ahmad Tohari's Lintang Kemukus as the data source conducted by (Tiwiyanti \& Retnomurti, 2017). The research shows that the translator should have translation competence and knowledge in translating culture-specific items.

\section{LITERATURE REVIEW}

\section{A. Translation}

Translation is a term that refers to three activities, namely product, process, and field. It is also important to stress that translation deals with the transfer of written text as there is another mode of translation in which the medium is oral, which is called interpreting or interpretation. In translating, the language from which a text is translated is known as source language (SL) and the language of the translated product is the target language (TL). What is also referred to as the original text is generally called the source text (ST), and the translated text is target text (TT) (Colina, 2015, pp. 2-4). A more comprehensive definition of translation is proposed by (Nida \& Taber, 1982), who state that translating consists in reproducing in the receptor language the closest natural equivalent of the source-language message, first in terms of meaning and secondly in terms of style. Based on this definition, there are at least three aspects in translation that need to be preserved, namely, equivalent, meaning, and style. A translator has to try to find the closest equivalent of the SL in the TL; it can be started from the micro level of a text such as word and phrase. In order to produce equivalent translation, a translator is demanded to maintain the meaning or message of the SL as well as its style or form.

In order to produce good and quality translation, the use of translation tools is necessary. Translation activity relates to tools, namely the writing instruments such as stylus, quill, and pen and also its material supports like wood, parchment, and paper. The tools of translation in earlier periods are not only the material objects that allow words to be permanently traced but they are the products of those tracings which in turn will assist translators in their 
tasks. In other words, translation is impossible to do without tools. (Cronin, 2003). The tool in translation activity is later developed rapidly along with the globalization era as well as the increase of translation needs. The advent of wiki-translation indicates that the rapid dissemination of online social networking practices not only generates new translation needs, but has farreaching consequences for the profession of translator in an age of globalization. With the Machine Translation (MT) at hands, the translation consumers are increasingly becoming translation producers. (Cronin, 2013).

Translation, as stated before, also refers to both academic and commercial fields. Therefore, it is included as one of courses learned in colleges and universities, and recently it becomes one of developing research fields. In Indonesia, translation grows rapidly in those fields; a lot of reference books written in English or in other foreign languages are translated into Indonesian to bridge the readers to the information contained in the books. In addition, translation is also done in other kinds of written materials, like novel, comic, magazine, poetry, verse, song, and so on. Today, translation is also found in digital media in various usages including online shop, online advertisement, website, and social media.

\section{B. Machine Translation}

According to Colina (2015) machine translation (MT) is the translation produced by a software program without the intervention of a human translator; usually the target text produced by a computer is not usable in its raw form (i.e., raw output). It has to be revised and edited by a human translator or editor. The process of editing and preparing machine-translated output for use by human is known as post-editing.

The use of MT in nearly all aspects of human life somehow affects the real role of human translators. The emergence of MT in social media features such as the Instagram again proves that translation is important, but human translator's role is seemingly not. However, the absence of human translator in this translation feature results in doubts whether the translation result of the MT meets the translation quality parameters or not, especially in dealing with culturally-bound terms. It is because MT cannot perform contextual knowledge system or knowledge of situation. This knowledge is one of the memories needed by translators in doing their work; they are knowledge of language system, knowledge of language use, knowledge of the world, and knowledge of situation (Mandelblit, n.d.). On the other hand, human translator is facilitated with many translation techniques, strategies, methods, and procedures to deal with difficult language units to translate. 
Machine translation can now be found in several social media providers, such as Facebook and Instagram. Instagram is a mobile application (iOS and Android) that enables users to instantly turn their mobile snapshots into visually appealing images, which are then shared with others on the network. Instagram launched in October 2010, was purchased by Facebook in April 2012, and currently has approximately 130 million monthly active users. (Salomon, 2013). Recently, Instagram has added a translation feature called See Translation under the caption and comment column that enables the users to look up the caption and comment in other languages. This feature is a corpusbased translation that translates the caption and texts by making use of linguistic database provided by the machine.

\section{Translation Techniques}

In translation process, cultural non-equivalence is the most frequent problem to emerge, as stated by (Hoed, 2006) that translating cultural items is not easy since the translator sometimes does not totally master the TL as the inseparable part of the TL culture. Many culturally-bound terms do not have one-to-one correspondence in the target language, for example Indonesian cultural terms joglo that cannot be translated into equivalence English term. The term joglo refers to a traditional house that can only be found in Central Java, and it is usually owned by the royal family. This kind of house is not recognized in other cultures. In that case, the translator is given some techniques of translation, such as borrowing technique; that is to borrow or maintain the original term of the source language as proposed by (Molina $\&$ Albir, 2002)

Another technique is also likely to apply, such as description technique; that suggests the translator to describe the term to avoid wrong translation. In description technique, the translator replaces the term or expression with a description of its form or function (Molina $\&$ Albir, 2002). For example, instead of mentioning the term joglo, s/he describes it based on its function and appearance.

However, in this article, there are three translation techniques to explain due to the research findings, namely literal, borrowing, and particularization.

1. Literal is to translate a word or an expression word for word,

2. Borrowing is to take a word or expression straight from another language.

3. Particularization is to use a more precise or concrete term (Molina $\&$ Albir, 2002) 
292 Celt: A Journal of Culture, English Language Teaching \& Literature, Volume 19, Number 2, December 2019, pp. 287 - 301

\section{Translation of Culturally-bound Terms}

As stated by House (2015), translation is more than a linguistic act, which is also an act of communication across cultures. Translation is one of the major means of constructing representation of other cultures (Nida in House, 2015). It is important to keep in mind that in translating, the translator does not merely change the source language (SL) text structure into the target language (TL) structure. Therefore, bilingualism and biculturalism are two things required for the translator.

Language and culture are inseparable aspects in translation activity since the former is one of the realization of the latter. Language is a means of communication that can be expressed both verbally and non-verbally. Nonverbal communication is expressed in form of symbols, gestures, pictures, and so on. Symbol itself can be seen in various media, one of them is clothes. For example, in batik, as one of Javanese cultural products, the symbol delivers certain messages and they mostly represent local values held by the society. The symbol is usually represented through the batik motif names.

Banyumas batik motifs have various names, such as kembang turi, lumbon truntum, wahyu temurun, bunga gesekan, kawung picis, and so on. Each of those names is the representation of the messages that the artisans want to deliver. When those names of batik motifs are intended to be translated, a translator should take into account the acceptability of both form and meaning of them in the target language. The message of the motif should be well-recognized by the target readers. Translating culturally-bound terms is one of the mostfrequent problems faced by a translator although $\mathrm{s} / \mathrm{he}$ is nowadays more equipped with translation tools. It is in line with one of research results conducted to investigate translation of cultural lexicon in a novel entitled Saman. The results show that Translating cultural terms needs cultural lexicons understanding in order to transfer the meaning and the message from the SL into the TL, so that it would not lead to confusion (Hilman, 2015).

\section{E. Translation Acceptability}

Acceptability is one of translation quality assessment parameters suggested by some scholars to evaluate translation quality. Larson (1984) prefers to call it naturalness since it deals with the naturalness of the translated text felt by the target readers. Meanwhile, Newark (1988) proposes the term acceptability in dealing with the assessment of the use of certain dictions in translating a text; the diction must be well-recognized by the target readers. Acceptability is the crucial part of translation assessment when dealing with cultural texts. 


\section{METHOD}

In collecting data, the researchers took some samples from two Instagram accounts containing batik motif names, namely @batikantodjamil and @batk_rd. Since the research belongs to qualitative research, the data taken are in forms of images and texts.

\section{A. Type of Research}

This research was conducted with qualitative method which rely on text and image data (Creswell 2013). To be called qualitative research, there are several basic characteristics that should be reflected in the research. Qualitative research should be conducted in a natural setting; qualitative researchers tend to collect data in the data field at the site where participants experience the issue or problem under study. In this type of research, the researcher is the key instrument that collects the data through examining documents, observing behaviors, or interviewing participants. Qualitative researchers also gather multiple forms of data such as interviews, observations, documents, and audiovisual information rather than a single data source. Those three characteristics were applied during this research. The researchers used text and image taken from Instagram accounts that are used as the subject of the research. The researchers also examined the data themselves by applying the translation theories as well as other documents to support the analysis.

\section{B. Research Subjects}

There were two Instagram accounts used as subjects for the research, namely@batikantodjamil and @batk_rd owned by two prominent batik centers in Banyumas. Those two accounts are chosen due to the reputation of the batik artisans in maintaining Banyumas batik motifs originality by being persistent in creating more Banyumas local motifs to be introduced to the national or international level. Their idealism is obviously seen in the batik they produce which mostly depict the local values and wisdom of Banyumas people and philosophy. Both@batikantodjamil and@batik_rd are used to promote their product to the world by mentioning the names of batik motifs in the caption column which are mostly taken from Banyumas local values.

Those batik motif names contained in the two Instagram accounts are the primary data of this research (see Picture 1). Meanwhile, the secondary data in this research is the result of interview with the owners of Anto Djamil and Rusmini Darmono batik center. The result of the interview is used to help the researchers analyzing the meaning of each batik motif in accordance with the analysis of translation technique of those batik motifs. The knowledge of the meaning behind the batik motif is important in determining the suitable technique of translation used, since translation is about meaning-transfer. 
294 Celt: A Journal of Culture, English Language Teaching \& Literature, Volume 19, Number 2, December 2019, pp. 287 - 301

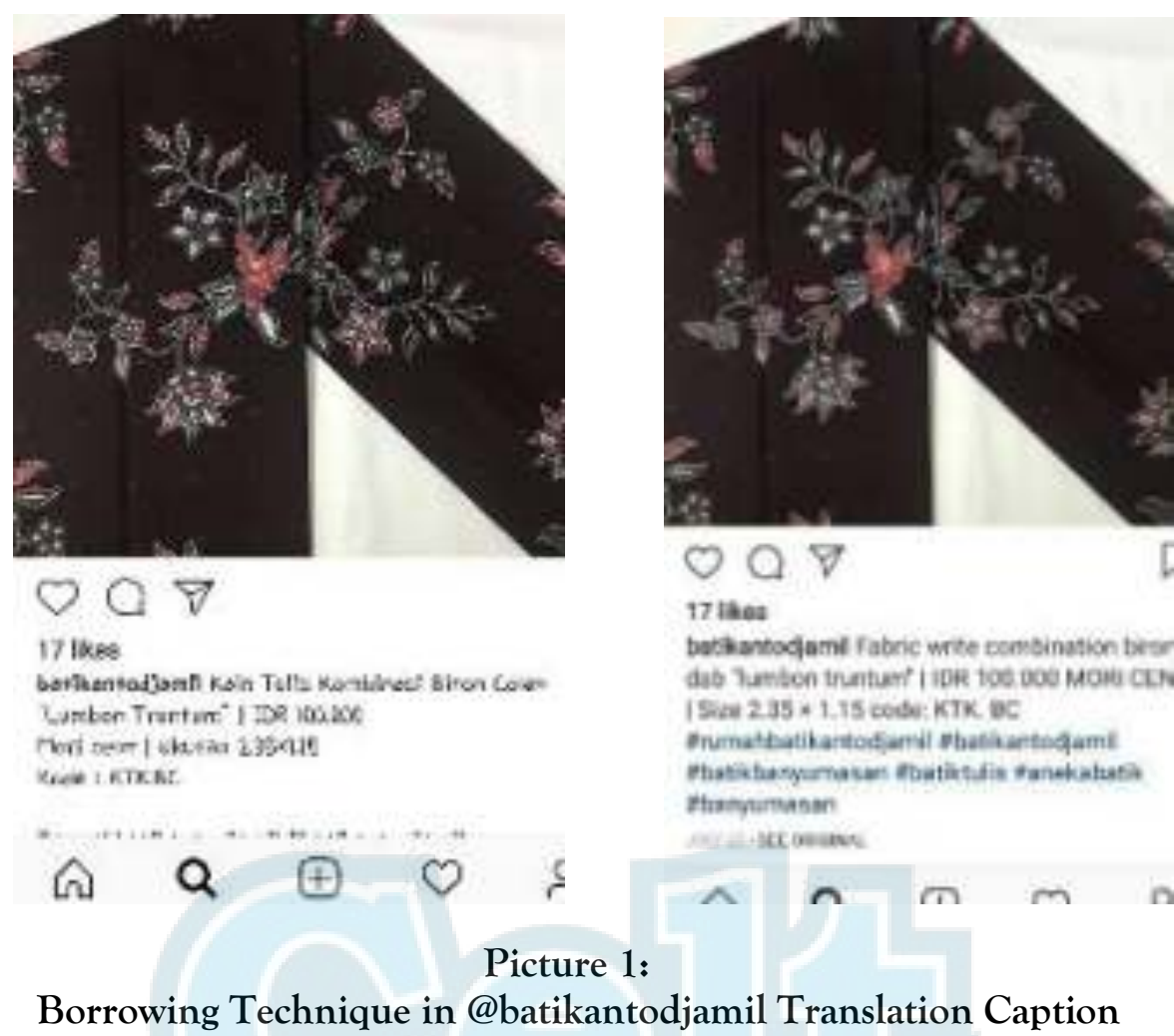

The unit of analysis of this research is therefore at the micro level of text, which is called phrase. It is said by Saldanha \& O'Brien (2014, p. 24) that the unit of data might be at the micro-level of 'text' and, while a researcher might analyze text in general, it is quite likely that the unit of analysis (or measurement) will be further broken down into measurable concepts such as lexical items, sentences, clauses, phrases, collocations and so on.

\section{Research procedure}

Since this research was conducted qualitatively, the researchers did some qualitative procedures before starting the analysis. Firstly, the researchers observed @batikantodjamil and @batik_rd Instagram accounts as the research subjects to gather the data needed. During the observation, the researchers collected the data that show batik motif names and the translation version. Secondly, the researchers classified the techniques used in the translation based on the theory applied. The researchers also did literature study about the meaning of the batik motifs used as the data to support the analysis of the translation. 


\section{RESULTS AND DISCUSSIONS}

In the data of this research, there are three translation techniques applied namely literal, borrowing, and particularization. Translation technique is a term to use when the focus of the research is the translation result, and the technique is the realization of translation strategies used in the process of translation. Here is the explanation of each technique found in the data.

\section{A. Literal}

In literal technique, the translator translates a word or an expression word for word. This technique is found in the following data:

\section{Datum 1}

This datum is taken from account @batikantodjamil. The batik motif Wahyu Temurun is translated into Hereditary Revelation which is derived from the lexical meaning of the words wahyu and temurun. In Merriam-Webster Online Dictionary, the word hereditary in this context is defined as an adjective referring to inheritance or heredity; while revelation refers to something that is revealed by God to humans. The translation is accurate since the meaning of the words is well-conveyed but it is less acceptable for the target readers. The target readers will be probably questioning about the meaning of hereditary revelation and it will be difficult for them to catch the philosophical meaning of the batik motif. The SL term of this motif, which is originally a Javanese term, consists of not only lexical meaning, but also sociocultural meaning that is defined by Suryawinata \& Hariyanto (2003, p. 120) as meaning that is related to cultural factors held by certain society; the naming of the batik motif is closely related to the local value of the Javanese people. Wahyu temurun means God's words delivered to human as the guidance in their lives. The The batik artisan wants to express divine message through the motif. Meanwhile, in the TL culture, this value does not exist.

\section{Datum 2}

In this datum, the batik motif Bunga Gesekan is translated into flower friction, and the technique employed is literal technique. The Instagram machine translation simply translates the lexical meaning of each word that construct the term. As a result, the SL term sounds unnatural, and the term is unaccaptable in the SL culture. Sometimes, batik artisans create batik motif by taking some inspiration from their surroundings. It also happens to the batik motif Bunga Gesekan which is taken from the surrounding flower plants. The word bunga here is literally translated into flower, while gesekan is translated into friction. Apparently, the Instagram machine translation only recognize the lexical meaning of the word, whereas in this term, the word gesekan refers to 
296 Celt: A Journal of Culture, English Language Teaching \& Literature, Volume 19, Number 2, December 2019, pp. 287 - 301

the technique of rubbing applied in creating such pattern to result fiber pattern of batik. However, the word friction is not equivalent to the meaning refered by the SL word, because friction itself is not recognized as a name of batik-making technique, or fabric-designing technique in general. If this batik motif is necessary to translate, a translator needs to find the suitable term to be naturally accepted by the target readers; yet it cannot be performed by machine translation.

\section{$\underline{\text { Datum } 6}$}

In addition, literal technique is also found in the translation of batik motif Waru Wajik in batik_rd Instagram account that is translated into Hibiscus Diamonds. In translation, equivalence of source language and target language is important, so the translator should find the closest equivalence between those two languages. The word waru is derived from Javanese language; in Indonesian it is called baru, a plant that belongs to malvaceae genus. It is translated literally into hibiscus. Whereas, the word wajik is translated into diamonds. Literally, the translation is accurate because it produced formal equivalence, but if we view it from cultural perspective, it seems that the translation does not represent the intention of the batik artisan who chooses to produce the batik motif with certain purposes, for example to introduce local wisdom in forms of culture, heritage, and even floral objects. The detailed information about the use of literal technique is shown in the following table.

Table 1:

The Distribution of Literal Technique

\begin{tabular}{clll}
\hline $\begin{array}{c}\text { Da- } \\
\text { tum }\end{array}$ & Account & \multicolumn{1}{c}{ Source Text } & \multicolumn{1}{c}{ Target Text } \\
\hline 1 & $\begin{array}{l}\text { @batikant } \\
\text { odjamil }\end{array}$ & $\begin{array}{l}\text { Kain Tulis } \\
\text { Kombinasi Biron } \\
\text { Colet "Wahyu } \\
\text { Temurun” }\end{array}$ & $\begin{array}{l}\text { Fabric write combination } \\
\text { biron dab "Hereditarry } \\
\text { Revelation" }\end{array}$ \\
\hline 2 & $\begin{array}{l}\text { @batikant } \\
\text { odjamil }\end{array}$ & $\begin{array}{l}\text { Kain Tulis } \\
\text { Kombinasi Biron } \\
\text { Colet "Bunga } \\
\end{array}$ & $\begin{array}{l}\text { Fabric write combination } \\
\text { biron dab "Flower friction" }\end{array}$ \\
\hline 6 & @batik_rd & $\begin{array}{l}\text { Batik Banyumas } \\
\text { Motif: Waru } \\
\end{array}$ & Batik Banyumas \\
& & Motive: Hibiscus Diamonds \\
\hline 5 & @batik_rd & $\begin{array}{l}\text { Batik Banyumas } \\
\text { Motif: Campur } \\
\text { sari }\end{array}$ & Batik Banyumas \\
& & Motive: Mix sari \\
\hline
\end{tabular}


Applied in the Translation of Batik Motif Names in See Translation

\begin{tabular}{llll}
\hline 8 & @batik_rd & $\begin{array}{l}\text { Batik Banyumas } \\
\text { Motif: Kawung } \\
\text { Picis }\end{array}$ & $\begin{array}{l}\text { Batik Banyumas } \\
\text { Motive: Kawung Cents }\end{array}$ \\
\hline 7 & @batik_rd & $\begin{array}{l}\text { Batik Banyumas } \\
\text { Motif: Sekar Jagat }\end{array}$ & $\begin{array}{l}\text { Batik Banyumas } \\
\text { Motive: Sekar Universe }\end{array}$ \\
\hline
\end{tabular}

\section{B. Borrowing}

Another translation technique found in the data is borrowing technique that means to take word or expression straight from another language. There are two types of borrowing technique, namely pure and naturalized borrowing. Here are some data with borrowing technique:

\section{Datum 3}

One of the examples of pure borrowing technique is found in batik motif lumbon truntum that is taken from account @batikantodjamil. The term lumbon truntum is maintained in the target language because the word lumbon and truntum are Javanese words and their lexical meanings cannot be found in the dictionary. The translation feature of the Instragam seemingly does not provide the corpus of this kind of term. It is seen from the technique chosen, which is borrowing technique. The technique is indeed commonly found in the translation of specific or culturally-bound terms whose one-to-one correspondence cannot be found in the target language.

Lumbon is derived from the word lumbu, or taro plant which refers to Javanese plant that is easily found in any season and any place. It symbolizes a Javanses local value that a person should be able to adapt in any situation and should be useful for other people as well as for the surrounding. Meanwhile, truntum is a Javanese word which means regrow, and it also carries a sacred philosophy that an old love will grow again along with the time. Some people also relate this batik motif to eternal love. Therefore, if the batik motif is translated based on its lexical meaning, the effect will be different and it will lose its cultural sense.

\section{$\underline{\text { Datum } 4}$}

In the next example, we can see another borrowing technique in the batik motif named Kembang Turi. The batik motif Kembang Turi is translated into Turi Cauliflower and the borrowing technique is found in the translation of the word turi. This word refers to a name of a flower found particularly in Central Java, and it hardly can be found in other countries. In translating such term, borrowing is one of translation techniques used most frequently. 
298 Celt: A Journal of Culture, English Language Teaching \& Literature, Volume 19, Number 2, December 2019, pp. 287 - 301

\section{$\underline{\text { Datum } 7}$}

Borrowing technique is also found in the translation of batik motif sekar jagat taken from@batik_rd Instagram account. This technique is applied in translating the word sekar. The word sekar is a Javanese term of bunga or flower in English, and because it belongs to local language variety, the lexical meaning of the word is not provided in the database of the Instagram translation feature. Therefore, the machine simply borrows the word to be transferred into the target language. Below is the complete information about the use of borrowing technique in the data that is shown in the following table.

Table 2:

The Distribution of Borrowing Technique

\begin{tabular}{|c|c|c|c|}
\hline $\begin{array}{l}\text { Da- } \\
\text { tum }\end{array}$ & $\begin{array}{c}\text { Accou } \\
\text { nt }\end{array}$ & Source Text & Target Text \\
\hline 4 & $\begin{array}{l}\text { @batik } \\
\text { antodj } \\
\text { amil }\end{array}$ & $\begin{array}{l}\text { Kain Tulis } \\
\text { Kombinasi Biron } \\
\text { Colet "Kembang } \\
\text { Turi" }\end{array}$ & $\begin{array}{l}\text { Fabric write combination biron } \\
\text { dab "Turi cauliflower" }\end{array}$ \\
\hline 3 & $\begin{array}{l}\text { @batik } \\
\text { antodj } \\
\text { amil }\end{array}$ & $\begin{array}{l}\text { Kain Tulis } \\
\text { Kombinasi Biron } \\
\text { Colet "Lumbon } \\
\text { Truntum" }\end{array}$ & $\begin{array}{l}\text { Fabric write combination biron } \\
\text { dab "Lumbon Truntum" }\end{array}$ \\
\hline 7 & $\begin{array}{l}\text { @batik } \\
\text { _rd }\end{array}$ & $\begin{array}{l}\text { Batik Banyumas } \\
\text { Motif: Campur sari }\end{array}$ & $\begin{array}{l}\text { Batik Banyumas } \\
\text { Motive: Mix sari }\end{array}$ \\
\hline 5 & $\begin{array}{l}\text { @batik } \\
\text { _rd }\end{array}$ & $\begin{array}{l}\text { Batik Banyumas } \\
\text { Motif: Sekar Jagat }\end{array}$ & $\begin{array}{l}\text { Batik Banyumas } \\
\text { Motive: Sekar Universe }\end{array}$ \\
\hline 8 & $\begin{array}{l}\text { @batik } \\
\text { _rd }\end{array}$ & $\begin{array}{l}\text { Batik Banyumas } \\
\text { Motif: Kawung Picis }\end{array}$ & $\begin{array}{l}\text { Batik Banyumas } \\
\text { Motive: Kawung Cents }\end{array}$ \\
\hline 9 & $\begin{array}{l}\text { @batik } \\
\text { _rd }\end{array}$ & $\begin{array}{l}\text { Batik Banyumas } \\
\text { Motif: Cempaka } \\
\text { Mulya }\end{array}$ & $\begin{array}{l}\text { Batik Banyumas } \\
\text { Motive: Cempaka Mulya }\end{array}$ \\
\hline 10 & $\begin{array}{l}\text { @batik } \\
\text { _rd }\end{array}$ & $\begin{array}{l}\text { Batik Banyumas } \\
\text { Motive: Manggar }\end{array}$ & $\begin{array}{l}\text { Batik Banyumas } \\
\text { Motive: Manggar }\end{array}$ \\
\hline
\end{tabular}




\section{Particularization}

Particularization is a technique in which the translator uses a more precise or concrete term. For example, the word anak-anak in Indonesian is translated into boys in English. The opposite technique of particularization is generalization. In Datum 4, there is a particularization technique in the translation of the batik motif kembang turi; the particularization occurs in the translation of the word kembang into cauliflower. Based on the lexical meaning, kembang means flower in English while cauliflower refers to a different object; it refers to the flower of cabbage and is usually cooked as vegetables. If those objects are compared, we can see that the term cauliflower is not accurate to represent the turi flower. To translate name of a cultural product, we can simply use borrowing technique to maintain the original term.

\section{CONCLUSION}

Based on the research result, there are some points that can be drawn into conclusion. There are three translation techniques found in the data, namely, literal, borrowing, and particularization, and borrowing technique is the most dominant one to apply. It is due to the way the machine translation works. Different from human translators, machine translation translates a text simply based on the linguistic corpus or database. In this case, the linguistic corpus of the Instagram translation feature still needs improvement so that it can produce more acceptable translation for the target readers. Machine translation is very helpful for human translators since it can produce more translation in relatively short time. However, the absence of human translator's role in a translation feature just like the one provided by the Instagram brings about unacceptable translation. It happens because machine translation cannot perform contextual knowledge in the translation process.

\section{ACKNOWLEDGEMENT}

We would like to express our gratitude to LPPM UNSOED for the opportunity and support so that the researchers in conducting the research. The other parties who also have been very helpful and cooperative are Rumah Batik Rusmini Darmono and Rumah Batik Anto Djamil in providing us with much information and knowledge about batik and the meaning represented in each name of the motifs. 
300 Celt: A Journal of Culture, English Language Teaching \& Literature, Volume 19, Number 2, December 2019, pp. 287 - 301

\section{REFERENCES}

Colina, S. (2015). Fundamentals Of Translation. Cambridge: Cambridge University Press.

Cronin, M. (2003). Translation and Globalisation. London and New York: Routledge.

Cronin, M. (2013). Translation in the digital age. In New perspectives in translation studies CN - P306.97.T73 C76 2013. https://doi.org/10.4324/9780203073599

Hilman, E. H. (2015). The Translation Of Indonesian Cultural Lexicons In The Novel Saman. Lingua Cultura, 9(61), 67-74.

Hoed, B. H. (2006). Penerjemahan dan Kebudayaan (First). Jakarta: PT Dunia Pustaka Jaya.

House, J. (2015). Translation Quality Assessment: Past and Future. London and New York: Routledge.

Larson, M. L. (1984). Meaning-Based Translation: a guide to cross-language equivalence. Lanham, MD: University Press of America.

Mandelblit, N. (n.d.). Machine Translation: A Cognitive Linguistics Approach Theoretical Approach Framework : the Cognitive Linguistics. 117-130.

Molina, L., \& Albir, H. (2002). Translation Techniques Revisited : A Dynamic and Functionalist Approach. META, 47(4), 498-512. https://doi.org/10.7202/008033ar

Newmark, P. (1988). A Textbook of Translation. New York: Prentice-Hall International.

Nida, E. A., \& Taber, C. R. (1982). The Theory and Practice of Translation. Leiden: E.J.Brill.

Pudjiati, D. (2018). Semantic Errors in the Translation into English about Actions to Defend Islam in 2016. Advances in Social Science, Education and Humanities Research, 154(Icclas 2017), 98-102. Atlantis Press.

Saldanha, G., \& O’Brien, S. (2014). Research Methodologies in Translation Studies. New York: Routledge.

Salomon, D. (2013). Moving on from Facebook: Using Instagram to Connect With Undergraduates and Engage in Teaching and Learning. College $\mathbb{8}$ Research Libraries

News,

$74(8)$ 408-412. 
Purwaningsih, D. R. \& Sholikah, I.M., Revealing Translation Techniques

Applied in the Translation of Batik Motif Names in See Translation

https://doi.org/https://doi.org/10.5860/crln.74.8.8991

Suryawinata, Z., \& Hariyanto, S. (2003). Translation: Bahasa Teori Eु Penuntun Praktis Menerjemahkan. Yogyakarta: Kanisius.

Tiwiyanti, L., \& Retnomurti, A. B. (2017). Loss and Gain in Translation of Culture-Specific Items in Ahmad Tohari;s Lintang Kemukus: A Semantic Study. Lingua Cultura, 11 (May), 1-6. https://doi.org/10.21512/lc.v11i1.1820

@batikantodjamil

@batik_rd 